IZA DP No. 7937

Common Law Marriage and Male/Female Convergence in Labor Supply and Time Use

Shoshana Grossbard

Victoria Vernon

January 2014

Forschungsinstitut zur Zukunft der Arbeit Institute for the Study of Labor 


\title{
Common Law Marriage and Male/Female Convergence in Labor Supply and Time Use
}

\author{
Shoshana Grossbard \\ San Diego State University \\ and IZA \\ Victoria Vernon \\ Empire State College, New York
}

\author{
Discussion Paper No. 7937 \\ January 2014
}

IZA
P.O. Box 7240
53072 Bonn
Germany

\author{
Phone: +49-228-3894-0 \\ Fax: +49-228-3894-180 \\ E-mail: iza@iza.org
}

\begin{abstract}
Any opinions expressed here are those of the author(s) and not those of IZA. Research published in this series may include views on policy, but the institute itself takes no institutional policy positions. The IZA research network is committed to the IZA Guiding Principles of Research Integrity.

The Institute for the Study of Labor (IZA) in Bonn is a local and virtual international research center and a place of communication between science, politics and business. IZA is an independent nonprofit organization supported by Deutsche Post Foundation. The center is associated with the University of Bonn and offers a stimulating research environment through its international network, workshops and conferences, data service, project support, research visits and doctoral program. IZA engages in (i) original and internationally competitive research in all fields of labor economics, (ii) development of policy concepts, and (iii) dissemination of research results and concepts to the interested public.
\end{abstract}

IZA Discussion Papers often represent preliminary work and are circulated to encourage discussion. Citation of such a paper should account for its provisional character. A revised version may be available directly from the author. 


\section{ABSTRACT \\ Common Law Marriage and Male/Female Convergence in Labor Supply and Time Use}

Does availability of common law marriage (CLM henceforth) in the U.S help explain variation in the labor force participation, hours of work and hours of household production of men and women over time and across states? As CLM offers more legal protection to household producers at the margin between single status and marriage, we expect it to discourage labor supply and encourage household production on the part of household producers who are married or cohabit. In the context of traditional gender roles this implies a negative association between availability of CLM and the labor supply of women who are either married or cohabit. Also assuming traditional gender roles, men are then expected to work more in the labor force when CLM is available. We analyze micro data from CPS-iPums for the period 1995-2011 to investigate labor outcomes and from the ATUS for the period 200311 to study effects on household production and total hours of work. Labor supply effects of CLM availability are almost always negative for cohabiting and married women, and sometimes also for single women. The effects of CLM on men's labor supply tend to be negative when samples include all men aged 18-35. However, for the groups that we identified as most likely to be affected by CLM availability - the youngest white men w/o college education - we find positive effects. Married non-black men and women and work less in home production under CLM.

JEL Classification: J12, J16, J22, K36

Keywords: labor supply, marriage, law and economics, household production

Corresponding author:

Shoshana Grossbard

Department of Economics

San Diego State University

San Diego, CA 92182-4485

USA

E-mail: shosh@mail.sdsu.edu 


\section{Introduction}

The association between labor supply and laws related to marriage and divorce has previously been analyzed both theoretically and empirically. Most of these studies have focused on effects of changes in divorce laws. This paper investigates whether availability of common law marriage (CLM henceforth) in the U.S helps explain variation in the labor force participation, hours of work and hours of household production of men and women over time and across states. To the extent that CLM facilitated specialization and trade in households following traditional gender roles the abolition of CLM could help explain some of the gender convergence in labor supply and time in household production that has been observed in recent decades.

States accepting CLM offer their heterosexual residents an additional way of organizing their living-together arrangements by offering a choice between regular marriage and CLM, the latter involving lower costs of entering marriage (with CLM there is no need for a marriage certificate or ceremony) and vaguer rules in case of divorce. CLM is established when couples cohabit and hold themselves out as spouses by calling each other husband and wife in public, using the same last name, filing joint tax returns, or declaring their marriage on applications, leases, birth certificates and other documents. There are no rules regarding cohabitation time required for such marriage. A short term cohabiting relationship may also be called "marriage" if both spouses agree. A cohabiting couple who are engaged to be legally married almost certainly show enough intent to be married to be considered "married" in a CLM state. Otherwise CLM is like marriage, including the requirement of an official court-mandated divorce in the event of separation and acceptance by all other states and government institutions dealing with tax collection and redistribution of income. ${ }^{1}$

\footnotetext{
${ }^{1}$ see Lind (2008) and the following links:

http:/ / video.about.com/marriage/How-to-Qualify-for-a-Common-Law-Marriage.htm;
} 
In many ways CLM resembles laws granting equal rights to cohabiting couples adopted in some Western European countries, Canada and Israel.

It follows from a number of theories of marriage that the better the legal protection states offer to married individuals specializing in household production in case of dissolution the more these individuals are likely to reduce hours of work in the labor force. To the extent that availability of CLM offers more legal protection to household producers at the margin between single status and marriage, it may discourage labor supply and encourage household production on the part of household producers who are married or cohabit. In the context of traditional gender roles this implies a negative association between availability of CLM and the labor supply of women who are either married or cohabit. Also assuming traditional gender roles, men are then expected to work more in the labor force when CLM is available. With gender roles inverted, namely with men more responsible for household production and women for bringing in income, the opposite is expected to hold.

We present a conceptual framework that leads us to these testable implications and to similar implications for singles: if traditional gender roles prevail CLM is expected to be associated with less labor supply by all women-in couple or single--and more labor supply by men-in couple or single. Our predictions are most relevant to people at the stage of couple formation, and therefore we limit our analyses to respondents under age 36. Furthermore our analytical framework leads to predictions regarding differential effects of CLM by education and ethnicity and helps us interpret effects of CLM on time spent on home production.

Our research is innovative in that we examine effects of changes in CLM availability rather than of changes in divorce laws. Previous research has mostly examined labor supply effects of the

http://Www.answers.com/topic/common-law-marriage ; http://Www.co.travis.tx.us/dro/common_law.asp;

http://Www.unmarried.org/common-law-marriage-fact-sheet.html. 
replacement of fault- and consent-based divorce laws with no-fault and unilateral divorce.

Differences in the timing of these replacements have been linked to changes in labor supply e.g. by Peters (1986), Gray (1998), Stevenson (2007) and Genadek et al. (2007). Another type of law that has been examined in the context of labor supply research is also related to divorce and deals with alimony rights in Canada (Chiappori et al. 2011). We also add to the literature that previous research has linked variation in legal regimes to labor supply but not to time in household production as measured in time use surveys.

As there are no large US data sets that include individual information on CLM, we base our empirical study on comparisons between states that do and don't offer CLM and on variation over time in the availability of CLM. Most US states used to recognize CLM but have abolished this form of marriage. As of 2014, common-law marriage could still be contracted in 11 states: Alabama, Colorado, Iowa, Kansas, Montana, New Hampshire (posthumously for purposes of inheritance), Oklahoma, Rhode Island, South Carolina, Texas, and Utah, as well as in the Navajo Nation and in the District of Columbia. Over the period covered by our data CLM was abolished by Ohio (Oct 1991), Idaho (1996), Georgia (1997), and Pennsylvania (2005), which provides us with a quasi-experiment that we use in our analysis of state-level and individual-level data.

We analyze micro data from CPS-iPums for the period 1995-2011 to investigate labor outcomes and from the ATUS for the period 2003-11 to study effects on household production and total hours of work. According to the CPS labor supply effects of CLM availability are almost always negative for cohabiting and married women, and sometimes also for single women. The effects of CLM on men's labor supply tend to be positive for the groups that we identified as most likely to be affected by CLM availability — the youngest, white men, and men without college education. According to the ATUS in states with CLM married men and women tend to spend less time on household production and single men more time. However, our ATUS results are not as reliable as those of the CPS: we can't include state fixed effects and we can't distinguish between home 
production benefiting respondents and that benefiting their spouse or partner. This distinction plays a central role in our theoretical framework.

The abolition of CLM in three states may have contributed to the convergence in labor supply of men and women, especially by causing increased labor supply among women. Furthermore, the abolition of CLM may also have caused such convergence by discouraging the labor supply of young white men without a college education.

The conceptual framework is presented next. We then present data, methods and results.

\section{Conceptual framework}

We derive predictions regarding effects of CLM on labor supply and home production of men and women and whether these effects are expected to vary by age, education, and race/ethnicity (white, black or Hispanic).

Consider heterosexual individuals who have a choice between three types of relationship status: single, cohabitation and marriage. Singles with romantic partners maintain separate residences and are not called 'couples'. Marriage involves an implicit or explicit contract implying rights and obligations that are especially valuable in case of divorce or death and if children are present. Cohabitation involves rights and obligations that lie in between those of single and married romantic partners. In cohabitation there is limited formal asset protection for the lower earning partner in case of separation, whereas marriage guarantees each spouse close to half of all joint assets (in equitable property division states), or half of all assets acquired in marriage (in community property states). Entry into cohabitation is cheaper than entry into marriage, in part due to different social expectations (e.g. saving the costs of a wedding). In CLM states couples who move in together are often considered married right away or after a short period of unmarried cohabitation.

Relationship status and labor supply. Married or cohabiting couples are likely to specialize, with one person doing more household production and the other more work in the labor force. A number of 
theories of marriage, including Becker (1973), have emphasized the role of traditional gender roles in such specialization. Such roles may have a biological basis, given that women give birth and breastfeed (see e.g. Alger and Cox 2013). To the extent that such traditional roles prevail we follow others in expecting that married women will work fewer hours for pay than cohabiting women (Stafford et al. 1977, El Lahga and Moreau 2007) and that women living in couple (married or cohabiting) will work less in the labor force than single women. The more legal protection they are offered for their home production, the more they will be willing to exit the labor force. Specialization and traditional gender roles also imply that men living in couple will work more in the labor force than single men. Whether married men will work more than cohabiting men does not follow: there may be compensating differentials such that men with more income may not be as willing to agree to marry (as they may lose more in case of divorce) and may prefer to cohabit (see Grossbard-Shechtman 1982).

$C L M$, relationship status and labor supply. Cohabitation often leads to marriage out of mutual consent, regardless of whether CLM is available, but in CLM states cohabitation may unilaterally lead to marriage because it can be claimed by one of the partners. Fixed costs are minimal. Therefore if CLM is available, entering marriage can be cheaper. The potential for specialization between men and women is more likely to be realized if costs of entry are low: with cheaper entry into marriage more people will be observed as cohabiting or married and will engage in more household production. Assuming traditional gender roles, this implies that CLM encourages women's household production and discourages their labor force participation and hours of work. Conversely, in CLM states the labor force participation of men in couples could possibly be higher and they could engage less in household production. It does not follow from this specialization argument that single men would work more in the labor force in CLM states or that single women would work less. 
Next, we introduce marriage markets and prices, in line with Becker's (1973) second demand and supply (D\&S) model of marriage with many interrelated markets defined by personal characteristics such as education and age, each "marriage" market establishing an equilibrium "price". ${ }^{2}$ According to Becker, the higher their price in marriage the more the individuals have access to the gain from marriage. ${ }^{3}$ Even though this price could be associated to labor supply Becker's $(1973,1981)$ theory of marriage does not address such association. Grossbard-Shechtman (1984) adapted Becker's second D\&S model of marriage and replaced its markets for brides and grooms with multiple markets for Work-In-Household (WiHo) defined as household production work of benefit to a spouse/partner. ${ }^{4}$ A price is established in each market.

In a heterosexual context men and women potentially supply WiHo to each other and have a demand for each other's WiHo. If traditional gender roles are followed women do more WiHo than men and, netto, markets will be for women's WiHo, with men on the demand side paying the price of women's WiHo. Therefore they may need to work in the labor force in order afford women's WiHo. The more men are likely to marry, the more they are likely to prepare themselves for marriage financially and work longer hours while single. The more women are likely to marry the more they expect to be paid for their WiHo and the more they are likely to reduce their labor force participation and hours of work while single. Consequently, to the extent that CLM increases the likelihood of marriage or cohabitation by reducing entry costs it will not only encourage labor supply by men in relationships (who need to pay for WiHo) but also by single men preparing themselves for such relationships. Single women may have reduced labor supply where CLM is available if they anticipate having more opportunities to work in WiHo and get paid for it. It is not clear whether availability of CLM will have a stronger negative effect on married women's labor

\footnotetext{
${ }^{2}$ Choo and Siow (2006) have a hedonic marriage market model inspired by Becker's second D\&S model.

3 This price is related to the sharing rule found in later models of marriage, such as Chiappori (1992).

${ }^{4}$ WiHo is called 'household labor' in Grossbard-Shechtman (1984). WiHo can include parenting work and often also benefits the self.
} 
supply than on cohabiting women's labor supply or vice-versa. Single women's labor supply is likely to vary less with CLM than that of women in couple.

If a group moves away from traditional gender roles and marriage markets are markets for men's WiHo and women pay the price of WiHo then CLM is likely to raise men's price in marriage markets and to cause increases in women's labor supply and decreases in men's labor supply.

CLM, Relationship Status and Age. The closer people are to the average age of entry into cohabitation or marriage, the more CLM is likely to affect their labor supply. The labor supply or other outcomes of older people is not as likely to be affected by laws that make it easier to enter marriage. If they are in couple they may have been married or cohabiting for extended periods of time and CLM availability plays little role in their lives. If they are single and well past the average age at marriage they may also be set in their ways (possibly in same-sex relationships) and not likely to be influenced by CLM availability. Therefore in the empirical work we focus on respondents under age 36 (in contrast, studies of labor supply and divorce laws such as Gray (1998) have used samples ages 18 to 55). We expect our predictions to apply more to respondents aged 18-25 than to those aged 26-35.

CLM, Relationship Status and Education. Where traditional gender roles prevail CLM encourages women's WiHo. To the extent that highly educated women are less interested in supplying WiHo at a price and using that income to avoid labor force participation (see Grossbard-Shechtman and Neuman 1988) and more interested in exchanging their own WiHo for a partner's WiHo, CLM will have a larger negative impact on the labor supply of women with low education than on that of women with high education. CLM is also more likely to have a positive impact on the labor supply of loweducation men than on that of highly educated men.

CLM, Relationship Status and black/white. It is possible that black women are less likely to obtain a price for their WiHo than is the case with white women (see Goldsmith et al 2007 for evidence on racial discrimination in marriage markets). In fact, they may be expected to pay men to induce them 
to marry, as was assumed by Cherry (1998). Consequently, by making it more feasible to obtain WiHo CLM may encourage labor force participation and lead to more hours of work among black women, regardless of their relationship status. So while CLM may have negative effects on the labor supply of white women who get paid for their WiHo it may have positive effects on the labor supply of black women if they have to pay for men's WiHo. Furthermore, CLM may discourage labor supply by black men working in WiHo. Also, blacks tend to be poorer than whites and may have had a higher tendency to select CLM where it has been available (Lind 2008).

Additional Factors that May Matter. When testing for labor supply effects of CLM on women, it is important to control for the level of welfare benefits. Under some circumstances when prices for WiHo go down women may switch from WiHo (in marriage or cohabitation) to welfare instead of from WiHo to labor supply in the labor force (see Grossbard 2005). If CLM raises marriage prospects or the benefits of cohabitation for women, increased WiHo may not have as noticeable a negative impact on women's labor supply; instead it may mean fewer women dependent on welfare. The higher the welfare benefits, the more CLM may be associated with changes in women's welfare exits rather than changes in labor supply.

Sex ratios are defined as number of men divided by number of women. Grossbard-Shechtman (1984) and Chiappori et al. (2002) predicted that sex ratios will be negatively associated with women's labor supply. It also follows from the same theoretical frameworks that men's labor supply will be positively associated with sex ratios. Effects of CLM could be more pronounced where sex ratios are low as long as they are not associated with a switch in the side paying the price of WiHo. If the price of WiHo is positive, then the higher the sex ratio, the higher the price of WiHo and the more CLM is likely to cause increases in men's labor supply. Women's labor supply are not as likely to vary negatively with availability of CLM and high sex ratios, as women may not want to translate their higher price into more supply of WiHo. Also the higher the sex ratio the less CLM will be associated with more household production by women. 
Other variables included in the regression models are discussed in Section 4.

CLM and Household production time. An effect of CLM on labor supply does not necessarily imply the opposite effect on household production as measured by the ATUS. A first reason for the difference is that the predictions discussed above were based on arguments about WiHo and not all household production is WiHo: WiHo only includes production that benefits the spouse or partner and for which the partner is willing and able to pay. Unfortunately, our data don't include information on who benefited from household production time. So a prediction that CLM increases WiHo and decreases labor supply doesn't necessarily translate into increased household production as measured by the ATUS. For instance, the person could be spending more time in self-oriented household production when CLM is available. A second reason for the difference is that the availability of CLM may also affect the price for WiHo and the propensity to subcontract production outside the household. Third, when CLM is available the couples that are formed may be selected according to different characteristics. For instance, low income people may be more likely to form couples given the lower costs of entry into marriage and high income people may be more reluctant to cohabit as they may worry about a poorer partner claiming some of their assets. In turn, such income effects will affect both the demand and the supply of WiHo and observed time in household production. In view of these considerations we don't necessarily expect women to work more in household production where CLM is available, will it necessarily be the case that where CLM is available men will work less in household production.

\section{Data and Sample Means}

We use two data sets in this study: micro data from CPS-iPums 1995-2011 and micro data from ATUS 2003-11. The first is used to estimate labor market outcomes and the second to estimate determinants of household production time and total work in labor markets and household production. 


\section{CPS-iPums 1995-2011':}

This is a large nationally representative dataset with information on demographic characteristics, labor market status, and identifiable cohabiting relationships. Three states abolished CLM over the time covered by this data: Idaho (1996), Georgia (1997), and Pennsylvania (2005). The main drawback is that not all cohabiting couples can be identified prior to 2007 , because only relationships between household heads and their partners were recorded, while other household members are assigned either married or single status. Therefore our sample will underestimate the share of cohabiting couples in the population for 1995-2006. This will not be a problem, because our variable of interest is not the time trend but the difference between CLM and non-CLM states, as long as the designation of a household head and the composition of other family members do not vary systematically by CLM status.

We select all US-born men and women for we want to exclude individuals who possibly made their marriage decision in another country. Excluding non-US citizens resulted in a disproportionate loss of married women since first generation immigrants are more likely to be married and less likely to cohabit compared to the rest of the US population. This selection affected the Hispanic sample the most: it shrank by more than one-third.

We choose to focus on young individuals aged 18 to 35. Younger people are more likely to be affected by the change in the marriage law as they are more likely to transition in and out of marriage and cohabitation, and they tend to own fewer assets, and thus would have more of an incentive to respond to changes in the costs of entry into marriage or cohabitation. Our sample includes 322,858 women and 293,045 men, of which around 21.5\% live in CLM states. According to Table 1 of sample means (means are weighted using weights provided in the survey), CLM states have a slightly higher proportion of married and a lower proportion of cohabiting residents.

Respondents from CLM states are on average less educated and live in states with lower median

\footnotetext{
${ }^{5}$ https://cps.ipums.org/cps/
} 
household income, and more likely to have children, be Hispanic, and work full time in the labor force. CLM states are more likely to be community property states, with lower welfare payments, lower unemployment rates, lower proportion of college-educated adults and lower share of urban population.

Figure 1 illustrates usual weekly hours of work among married, cohabiting and single men and women living in CLM and non-CLM states. This measure of usual hours is the average among employed and non-employed individuals and thus may reflect higher probability of being employed and/or longer work week among some groups. Weekly work hours range between 26-43 hours. Cohabiting and single young adults of both genders, as well as married men, who live in CLM states, report longer workweeks. For example, cohabiting men, single men and single women work at least an hour longer per week than their counterparts in non-CLM states. In contrast, married women from CLM states work a few minutes less than their non-CLM counterparts.

ATUS 2003-11': This dataset is a time use supplement to the CPS. The survey is conducted several months after the CPS, and respondents are asked to update the main demographic, labor market and family status variables. The sample size is much smaller than that of the CPS because only one household member is selected to participate, and the supplement covers a shorter number of years. The shorter time frame makes causal interpretation of our results problematic since only one state changed CLM status during the 8 years of the survey. We therefore examine correlations and interpret our results with caution.

Our sample includes 14,201 women and 10,140 men aged 18-35, 20\% of whom live in CLM states. Survey weights are applied in all estimations to adjust for days of the week. Comparing the ATUS sample means in Table 1 to the CPS means, one notices that ATUS respondents are slightly older, more educated, more likely to be married and less likely to cohabit. These differences are possibly the result of a higher response rate to the supplement among educated women who are

\footnotetext{
${ }^{6}$ http://bls.gov/tus/
} 
also more likely to be married. The ATUS also contains a lower percent of African American women and a higher share of students. A higher proportion of ATUS respondents work full time, but the total weekly hours of work are about the same across both surveys.

Household production time includes all unpaid work: cooking, cleaning, food and non-food shopping, paying bills, care of adults, children, and pets, as well as using household and government services. Work includes paid work and income generating activities, although the latter accounts for only 2 minutes per person on average. Both household production and work include related travel and commute. Figure 2 reports minutes spent in paid and unpaid work by relationship status (married/cohabiting / single) in CLM and non-CLM states.

Married women in CLM states spend less time in household production and paid work on a typical day, overall $13 \mathrm{~m}$ less in total work compared to married women in non-CLM states. In contrast, cohabiting women in CLM states spend $19 \mathrm{~m}$ more in household production and $26 \mathrm{~m}$ more in paid work, overall $45 \mathrm{~m}$ more in total work compared to their counterparts in non-CLM states. There is virtually no difference in total work among single women who spend $3 \mathrm{~m}$ less in household production but $6 \mathrm{~m}$ more in paid work in CLM states.

Married men from CLM states spend 16m less in household production and 8m more in paid work, and thus only $8 \mathrm{~m}$ less in total work, than men in other states. Cohabiting men work $2 \mathrm{~m}$ more at home and $25 \mathrm{~m}$ less at work, or 23m less in total, compared to non-CLM men. In contrast, single men from CLM states work $8 \mathrm{~m}$ longer at home and $24 \mathrm{~m}$ longer at work, or over half an hour more than their counterparts in non-CLM states.

Notice that the CPS and the ATUS tell different stories about paid work hours of cohabiting men from non-CLM states. Their hours are longer than those of other men in ATUS, which is not the case in the CPS where married men work more per week. Paid work numbers for other groups are consistent across the two surveys. 


\section{Empirical Strategy}

Our general empirical strategy is to estimate a series of models where $Y$, the outcome of interest, is a function of CLM and other determinants of a decision. Identification of a CLM effect arises through cross-state variation and variation over time, as at least one state abolished CLM over the period examined. For individual $i$ from state $s$ in year $t$, outcome $Y$ is:

$$
\mathrm{Y}_{\text {ist }}=\alpha_{1} \mathrm{CLM}_{\mathrm{st}} * \text { Single }_{\text {ist }}+\alpha_{2} \mathrm{CLM}_{\mathrm{st}} * \mathrm{Cohabit}_{\text {ist }}+\alpha_{3} \mathrm{CLM}_{\mathrm{st}} * \text { Married }_{\text {ist }}+\beta \mathrm{X}_{\text {ist }}+\delta_{\mathrm{s}}+\gamma_{\mathrm{t}}+\mathrm{u}_{\text {ist }}
$$

where $Y$ is employment status, whether the individual is employed full time (worked 35 hours or more last week), and the number of hours worked last week in the labor force;

CLM is the indicator for whether the state of residence recognizes CLM in year $t$, our variable of interest;

$\delta_{\mathrm{s}}$ are state fixed effects to account for unobservable differences in economic, legal, demographic and cultural environment that may affect individual choices;

$\gamma_{\mathrm{t}}$ are time dummies to capture the time trend; and

$\mathrm{u}_{\mathrm{ijt}}$ are i.i.d. error terms.

The vector of controls $X$ consists of:

a. Respondent's demographics. All regressions contain indicators for married and cohabiting status, a quadratic function of age, student status and metropolitan residence. Regressions for the entire sample include respondent's educational level and black, Asian and Hispanic ethnicity. We also include presence of children of preschool and school age and number of children. CPS models include the log of unearned household income measured as the total household income minus the respondent's personal income. This variable is not included in ATUS models because of too many missing values. We also experimented with including partner's age and education in regressions for couples, but these variables did not significantly alter the results. 
b. State-level time-varying characteristics. This group of variables includes sex-ratio by age, which has been shown to affect labor market participation (Amuedo-Dorantes and Grossbard $2007)^{7}, \log$ of median household income, unemployment rate to account for the aggregate impact of the cost of living and economic environment, share of college-educated adults age 25 and older and share of urban population in the state to reflect social norms and bargaining conditions affecting markets for work in household production, and whether a state has a community property division rule in case of divorce, which is likely to affect bargaining power in marriage (Ekert-Jaffe and Grossbard 2008).

c. Year and state fixed effects. State fixed effects are included in CPS models to account for all other differences in the legal, cultural and economic environment that are not reflected in state time-varying controls such as laws regarding child custody and religiosity. However, our time use models do not include state fixed effects because only Pennsylvania changed CLM status between 2003-11, so it would not be possible to keep the CLM variable of interest and all state dummies. In addition, the sample size is already relatively small (several states have fewer than 100 observations). Instead of using state fixed effects, we include 3 regional dummies to account for Northeastern, Midwestern, and Western states, Southern being the reference.

The coefficients of interest are the coefficients on interactions of CLM with single, cohabiting and married status $\left(\alpha_{1}, \alpha_{2}\right.$ and $\left.\alpha_{3}\right)$. If traditional gender roles prevail it is expected that all these coefficients in regressions of labor supply will be positive for men and negative for women. The effect of CLM on labor market outcomes for married individuals may be larger than for cohabitants and singles.

We also estimate the following models using the ATUS for minutes spent in household production and total work:

${ }^{7}$ More information about the sources of data and how sex ratios are computed can be found in the notes to Table 1. 
Household $\operatorname{Prod}_{\text {ist }}=\alpha_{1}{ }_{1} \mathrm{CLM}_{\mathrm{st}} * \operatorname{Single}_{\mathrm{ist}}+\alpha_{2}{ }_{2} \mathrm{CLM}_{\mathrm{st}} * \mathrm{Cohabit}_{\text {ist }}+\alpha_{3} \mathrm{CLM}_{\mathrm{st}} * \mathrm{Married}_{\text {ist }}+\beta \mathrm{X}_{\mathrm{ist}}+\delta_{\mathrm{s}}+\gamma_{\mathrm{t}}+\mathrm{u}_{\text {ist }}$

Total Work ist $=\alpha{ }_{1} \mathrm{CLM}_{\mathrm{st}} * \operatorname{Single}_{\text {ist }}+\alpha{ }_{2} \mathrm{CLM}_{\mathrm{st}} * \mathrm{Cohabit}_{\text {ist }}+\alpha{ }_{3} \mathrm{CLM}_{\mathrm{st}} *$ Married $_{\text {ist }}+\beta \mathrm{X}_{\mathrm{ist}}+\delta_{\mathrm{s}}+\gamma_{\mathrm{t}}+\mathrm{u}_{\mathrm{ist}}$

We expect a positive coefficient on the interaction of CLM and cohabiting status in the household production regression for women and negative coefficient in that equation for men, to the extent that cohabiting partners in CLM states have an extra incentive to specialize. We do not have predictions regarding total work.

When investigating whether changes in CLM laws help explain variation in time use we present separate results for different age groups, ethnic groups, education groups and groups differing in relationship status. One reason to separate by age is that young people are more likely to adapt to changes in law such as the abolition of CLM. We separate by ethnicity and education in view of the reasoning in Section 2.

When analyzing the ATUS data we used Tobit and OLS regressions. Consistent with Stewart (2013), the results were similar. We chose to report marginal effects from Tobit models.

\section{Results}

We first present results regarding the effect of CLM on labor supply based on the CPS. Three labor outcomes are considered: employed, employed full time, and usual weekly hours of work. Then we present results regarding time in household production and total work time based on the ATUS.

\section{Labor supply outcomes}

Estimations for a CPS sample of native-born men and women aged 18-35 are reported in Tables 2 to 4 and summarized in Table 5. Our principal focus is on the coefficients of CLM (common law marriage) interacted with three possible living arrangements: single, married and 
(unmarried) cohabitation (in bold). Table 2 aggregates those aged 18-35 of all education levels and ethnicities. Tables 3 and 4 are for those without and with college education respectively. It can be seen from the first three columns in Table 2 that after control for a large number of variables and including fixed time and state effects married women work about 64 minutes less in the labor force and are less likely to be employed and have full-time employment when CLM is available than when it is not. CLM has a similar impact on cohabiting women, with work minutes decreasing by 50 minutes. Single women are less likely to be employed full time. The last three columns in Table 2 show results for men: single men are less likely to be employed when CLM is available. No significant effects of CLM are found for men aged 18-35 living in couple, whether married or not. The rest of the variables included in the regressions mostly have the expected signs.

Results differ when we separate samples by age category, education and race. Table 3 reports results of regressions similar to those in Table 2 but only for respondents without a college degree (the rest of the coefficients are available upon request). The effects of CLM availability on labor outcomes of men and women are shown separately for two age groups: ages 18 to 25 and 26 to 35 . Effects of CLM differ considerably across these age groups for both men and women. First, we look at the first three columns for women. When women of all ethnic groups are combined or when we only look at white women we find that CLM has negative effects on the labor supply of women aged 18-25 without college education that are similar to the effects we reported for the complete sample in Table 2 but these negative effects are not found for all and white women aged 26-35 (instead we find a positive effect on the employment probability of single women). Negative effects on Hispanic women's labor supply are mostly found for the 26-35 age group and are particularly large: a reduction of almost 8 weekly hours. In contrast, there are no negative effects of CLM on black women's labor supply and some positive effects: black women without college aged 18-25 who cohabit are more likely to be employed full-time and work longer hours. 
Columns 4 to 6 in Table 3 show results for men without college. It can be seen that for men aged 18-25 and without a college education availability of CLM has a large positive impact on most labor outcomes if they are married or cohabit: married men in this age/education group are more likely to be employed and to have full-time (FT) employment and cohabiting men work 68 minutes more when CLM is available than when it is not. These results for 'all ethnicities' mostly reflect results for white men. In contrast, for men aged 26-35 availability of CLM is not associated significantly with labor outcomes, except for a negative association for employment of cohabiting white men. CLM does not appear to affect labor outcomes for black men without a college education. When CLM is available single Hispanic men aged 18-25 work considerably more hours.

Table 4 presents results for the college-educated. Due to smaller numbers we combine all those aged 18-35. Even so, results for college-educated blacks and Hispanics are less reliable due to small sample size. A negative association between CLM and labor supply is found for married and cohabiting women with a college degree when all ethnicities are combined and for white women. In addition, single white women also have a lower employment probability where CLM is available. As for men it appears from Table 4 that for college-educated single white men there is a positive association between CLM and hours of work. However, that association is negative for collegeeducated Hispanic men regardless of their marital status. Hispanic college-educated men are also less likely to work full-time where CLM is available. No associations between CLM and labor supply were significant for black men or women with college degrees.

Robustness checks. Results in Table 2 shows that these results are robust to various changes in specification. Results (available upon request) were very similar when we dropped the following control variables: children-related variables, unearned income, student status, and state characteristics out of concern for lack of exogeneity. When we kept all the control variables included in Table 2 but dropped the interaction terms between CLM and marital status it still 
appears that CLM has negative effects on women's full time employment and hours of work as well as on men's probability of being employed.

We also tested for the robustness of the first three regressions reported in Table 3 for respondents without college of all ethnicities and aged 18-25. Again, we dropped children-related variables, unearned income, student status, and state characteristics. Results are very similar for single women. For married women in the alternative model all three labor outcomes were negatively affected by CLM (employment probability too). However, CLM effects on labor outcomes of cohabiting women were no longer significant. For men the alternative models show positive effects of CLM for married and cohabiting men that are almost identical to those reported in Table 3. Our results thus seem robust.

\section{Summary and Discussion}

Results for labor outcomes are summarized in Table 5. Most labor supply effects of CLM are negative for women, especially for women aged 18-25 and non-black. This holds for women with and without college. All cases of significant effects of CLM on the labor supply of women in couple (married or not) are found to be negative. This supports a specialization argument combined with traditional gender roles as well as our interpretation based on men paying for women's WiHo (see Section 2). We also find more cases of CLM discouraging single women's labor supply than encouraging it, especially among younger women with no college: the availability of a cheap marriage alternative may have encouraged these young women to reduce their hours of work while single in anticipation of payments for their WiHo. The only group of women in couple for which we find a positive association between labor supply and CLM are cohabiting black women lacking a college degree. This is consistent with black women experiencing relatively less favorable marriage market conditions relative to white women and possibly paying men for marriage, as modeled by Cherry (1998). Could it be that among blacks women may have to work more in the labor force to 
afford men's WiHo in a regular or CLM marriage? ${ }^{8}$ Based on our results for women we thus conclude that the abolition of CLM may have been a factor encouraging gender convergence, at least among non-blacks.

Results regarding the effect of CLM on men's labor supply are not as clear. It can be seen that most statistically significant effects of CLM for men are positive. This includes a number of positive effects for white men (and men of all ethnicities) without college aged 18-25. However, for men with a college education we get mixed results, with most regressions showing no significant effects, a positive effect on hours of work of white single men, and a negative effect for Hispanic men. We also get no significant effects for men without college aged 26-35. For the entire sample we only get a negative effect for single men's labor force participation. Given that the positive effects on (white) men aged 18-25 who are either married or cohabiting are strong and span all three labor outcomes we conclude that we found some support for the interpretation proposed in Section 2: CLM may encourage traditional men's entry into cohabitation and marriage and therefore to increase their labor supply so they can afford to pay for women's WiHo. Young men without a college degree and are the least marriageable would be the most influenced by the low-cost marriage alternative offered by CLM. White men would also be most influenced by CLM laws given that they are more likely to have to pay for WiHo. For these groups of young men-without college and not black--it follows that the abolition of CLM in three states may have contributed to reductions in labor supply over the period of investigation.

Our theoretical framework helps explain why we get mostly negative CLM effects on women's labor supply and why these effects for men are more likely to be positive. It also helps explain why our results apply to educated women but not to educated men. Educated men may stand to lose more from CLM in case of divorce or separation relative to educated women: if they cohabit and

\footnotetext{
${ }^{8}$ This would imply that in dating markets black women who have a higher labor supply are more likely to find a partner. This will be tested in future work.
} 
their female companion unilaterally transforms the cohabitation into marriage, men with higher incomes stand to lose more than less educated men, for they would then have obligations to share their relatively high earnings with the women they form couples with. They may therefore prefer not to earn as much and work less in the labor force. College-educated women following traditional gender roles are typically less invested in the labor market and are less likely to loose from CLM in case of separation than their male counterparts. Finally, the framework helps explain why whites and Hispanics-especially the less educated men--are more likely to respond to CLM than blacks. If they follow traditional gender roles non-black men are more likely to have to pay for women's WiHo and therefore to work to afford marriage or cohabitation.

\section{Household production and total hours of work}

We use the ATUS to estimate CLM's effect on household production and total "work" by marital status category. However, not all time spent on household production is 'work' in the sense of WiHo. Some of it is time spent producing for oneself, which can be considered leisure.

Nevertheless, we have followed standard procedures in the time use literature, added minutes spent on home production to minutes of work in the labor force and called this 'total work'. Another caveat is that the effects of CLM on hours of work in the labor market are not always the same according to the CPS and the ATUS, in part due to the longer time span of the CPS data. Tobit marginal effects are presented in Tables 6 and 7. When all respondents aged 18 to 35 are included (Table 6) it can be seen that single and married women perform less household production when CLM is available. From Table 7 it appears that his result holds for single women under age 26 and married women aged 26-35, especially for white and Hispanic women and women without a college degree. Married women in CLM states spend around 15 min less per day in both kinds of 'work' and cohabiting women in CLM states 'work' more overall than in other states (Table 6). This applies to non-black women and to college-educated women (Table 7). 
Married men do 10-31 min less in household production in states where CLM is available (Tables 6 and 7). Single men aged 26-35 in CLM states spend 19 min more in household production. Non-black single men from CLM states spend up to 30 min more per day in total 'work' compared to single men in other states. Single black men in CLM states spend less time in total 'work' compared to black men residing in non-CLM states (However, here results are less reliable: the sample of black men contains only 1,219 observations.) Cohabiting men aged 26 and older spend an hour less 'working' compared to cohabiting men in other states.

The simple effects of marriage and cohabitation relative to single status are as follows: marriage (cohabitation) increases women's involvement in household production by 38 (33) min per day and men's by 28 (27). Compared to their single counterpart, married (cohabiting) women spend 16 (11) min more in total 'work' per day, and men up to an hour more.

\section{Discussion.}

The theoretical framework explains why married non-black men work less in home production and more for pay in CLM states: they are working more in the labor force to pay for the WiHo supplied by women. Using the CPS we found that CLM availability was also associated with lower labor supply of married women, which was consistent with this finding for men. However, the ATUS analysis shows that effects of CLM on home production by married and single women are mostly negative and that under CLM married women 'work' less in total. It is mostly low-education and non-black married women who seem to benefit from a reduced 'work' load under CLM. An argument based on specialization and the concept of WiHo implies that under CLM married women in groups following traditional gender roles will work less in the labor force and do more WiHo. Could that mean less time in household production? It could: women may increase hours of WiHo benefiting their husbands while reducing their overall household production time, implying large reductions in home production benefiting the women themselves. Also, CLM may cause increases in men's aggregate demand for WiHo leading to higher prices for women's WiHo. If 
women's individual supplies of WiHo are backward-bending higher prices will mean less time spent in WiHo. That the reduction in household production time associated with CLM applies to married women with no college education and to non-black women supports the possibility that men's demand for WiHo plays a role here. For these groups demand is more likely to increase under CLM: women without college are more likely to be interested in supplying WiHo to men and nonblack women are more likely to benefit from positive discrimination in marriage markets (see Section 2). Therefore prices for the WiHo of these groups are more likely to increase. As the price of WiHo rises women's value of time is likely to increase and women's total time in household production (including time benefiting themselves) may decrease.

The ATUS results may also reflect state effects that were controlled for in the CPS analyses, since the ATUS does not allow us to include state fixed effects. Finally, our results may reflect a possible selection bias. If CLM states create incentives for weaker couples to be formed, one would observe that couples in CLM states tend to invest less in marriage-specific capital.

Some of the same considerations may also help reconcile the following findings: based on the ATUS that total hours of 'work' of cohabiting women with a college degree are higher where CLM is available and their total 'work' load is higher in those states. However, according to the CPS (which contains more years of observations, allowing us to include fixed state effects) non-black cohabiting women's hours of work in the labor force are lower where CLM is available.

\section{Conclusions}

This paper examined whether the availability of Common-Law Marriage (CLM) helps explain variation in the labor supply of men and women in the U.S. Our conceptual framework led us to expect that where traditional gender roles prevail CLM would be associated with less labor supply by women and more labor supply by men. This could hold not only for people who live with a partner or spouse but also for singles preparing themselves for forming a household specializing 
along traditional gender roles. CLM availability would be most relevant to the labor supply people at the stage of couple formation, namely younger people and its impact would be stronger among groups most likely to specialize regarding household production and work for pay. This includes groups among whom traditional gender roles are more likely to prevail.

An analysis of the CPS for respondents under age 36 revealed that most labor supply effects of CLM availability are negative for women. CLM led to reductions in the labor supply not only of cohabiting and married women, but also (to a lesser degree) of single women. Most statistically significant effects of CLM for men are positive. This includes a number of positive effects for white men (and men of all ethnicities) without college aged 18-25. However, for men with a college education we get mixed results, with most regressions showing no significant effects.

CLM may make marriage more affordable for low education men living in groups emphasizing traditional gender roles, which is more likely to be the case for whites and Hispanics than for blacks. When CLM was abolished it may have created some cases of "discouraged husbands" who had been willing to work towards a relatively cheap CLM marriage but were unprepared for regular (and more expensive) marriage. As expected we found this scenario to fit young men without a college degree more than those who finished college.

ATUS results regarding CLM and men's time spent on household production are consistent with this interpretation. One way to reconcile the ATUS results for married women—showing fewer hours of household production in CLM states - with the CPS results on labor supply is to make a distinction between WiHo (Work-In-Household) and household production benefiting the self.

The abolition of CLM in three states may have contributed to the convergence in labor supply of men and women, especially by causing increased labor supply among women. Furthermore, the abolition of CLM may also have caused such convergence by discouraging the labor supply of young men, especially among younger age groups without college education, whites, and Hispanics. 
So far social scientists have paid limited attention to variation in Common Law Marriage (CLM). This paper is calling attention to the potential impact of these old-fashioned laws on labor supply and time spent of household production. Further research will hopefully add more insights by using better U.S. data—such as longer data series making it possible to use fixed state effects in more regressions_-and providing comparisons with the effects of similar legal changes in other countries.

\section{References}

Alger, Ingela and Donald Cox.(2013). “The Evolution of Altruistic Preferences: Mothers versus Fathers" Review of Economics of the Household 11(3):421-446.

Amuedo-Dorantes, Catalina and Shoshana Grossbard, (2007). “Marriage Markets and Women's Labor Force Participation," Review of Economics of the Household 5:249-278.

Becker, Gary S. (1973). “A Theory of Marriage: Part I.” Journal of Political Economy 81(4): 813-846. . (1981). A Treatise on the Family. Cambridge: Harvard University Press.

Cherry, Robert.(1998) "Rational Choice and the Price of Marriage.” Feminist Economics 4:27-49.

Chiappori, Pierre-Andre. (1992). "Collective Labor Supply and Welfare." Journal of Political Economy 100(3):437-67.

Chiappori, Pierre-Andre, Bernard Fortin and Guy Lacroix. (2002). Marriage Market, Divorce Legislation, and Household Labor Supply. Journal of Political Economy 110: 37-72.

Chiappori Pierre-André , Murat Iyigun, Jeanne Lafortune, and Yoram Weiss. (2011). « Are IntraHousehold Allocations Policy Neutral? Theory and Empirical Evidence” IZA DP No. 5594 March. 
Choo, E., and A. Siow. (2006). "Who Marries Whom and Why." Journal of Political Economy 114(1): 175-201.

Ekert-Jaffe, Olivia and Shoshana Grossbard. (2008). "Does Community Property Discourage Unpartnered Births?" European J of Political Economy 24(1):25-40.

El Lagua, and Nicolas Moreau (2007). "The Effects of Marriage on Couples' Allocation of Time Between Market and Non-Market Hours", IZA DP No. 2619, February.

Genadek, Katie R. Wendy A. Stock, Christiana Stoddard. (2007). "No-Fault Divorce Laws and the Labor Supply of Women with and without Children.” Journal of Human Resources 42(1): .

Goldsmith, A., D., Hamilton, and W. A. Darity Jr. (2007). "From Dark to Light: Skin Color and Wages Among African-Americans.” Journal of Human Resources 42(4): 701-738.

Gray, Jeffrey S. (1998). “Divorce law changes, household bargaining, and married women’s labor supply." American Economic Review 88:628-42.

Grossbard, Shoshana.(2005) "A Theory of Women's Welfare Dependency, Marriage, and Labor Supply," Labour 19:211-241.

Grossbard-Shechtman, Amyra. (1982). "A Theory of Marriage Formality: The Case of Guatemala," Economic Development and Cultural Change 30(4): 813-830.

_ (1984). "A Theory of Allocation of Time in Markets for Labor and Marriage." Economic Journal 94:863-82.

Grossbard-Shechtman, Shoshana A. and Shoshana Neuman (1988). "Labor Supply and Marital Choice." Journal of Political Economy 96:1294-1302.

Lind, Goran. (2008). Common Law Marriage: a Legal Institution for Cohabitation. New York: Oxford University Press.

Peters, Elizabeth H. (1986). "Marriage and divorce: informational constraints and private contracting." American Economic Review 76:671-78. 
Stafford, Rebecca, Elaine Backman and Pamela Dibona. (1977). "The Division of Labor among

Cohabiting and Married Couples", Journal of Marriage and the Family, 39(1): 43-55.

Stevenson Betsey. (2007). “The Impact of Divorce Laws on Marriage-Specific Capital”, Journal of Labor Economics 25:75-94.

Stewart, Jay. (2013) “Tobit or not tobit?” Journal of Economic and Social Measurement, 38(3): 263-290. 
Figure 1. Usual Weekly Hours of Paid Work for Women and Men by Presence of CLM and Type of Living Arrangement. US-born individuals ages 18-35, CPS 1995-2011.
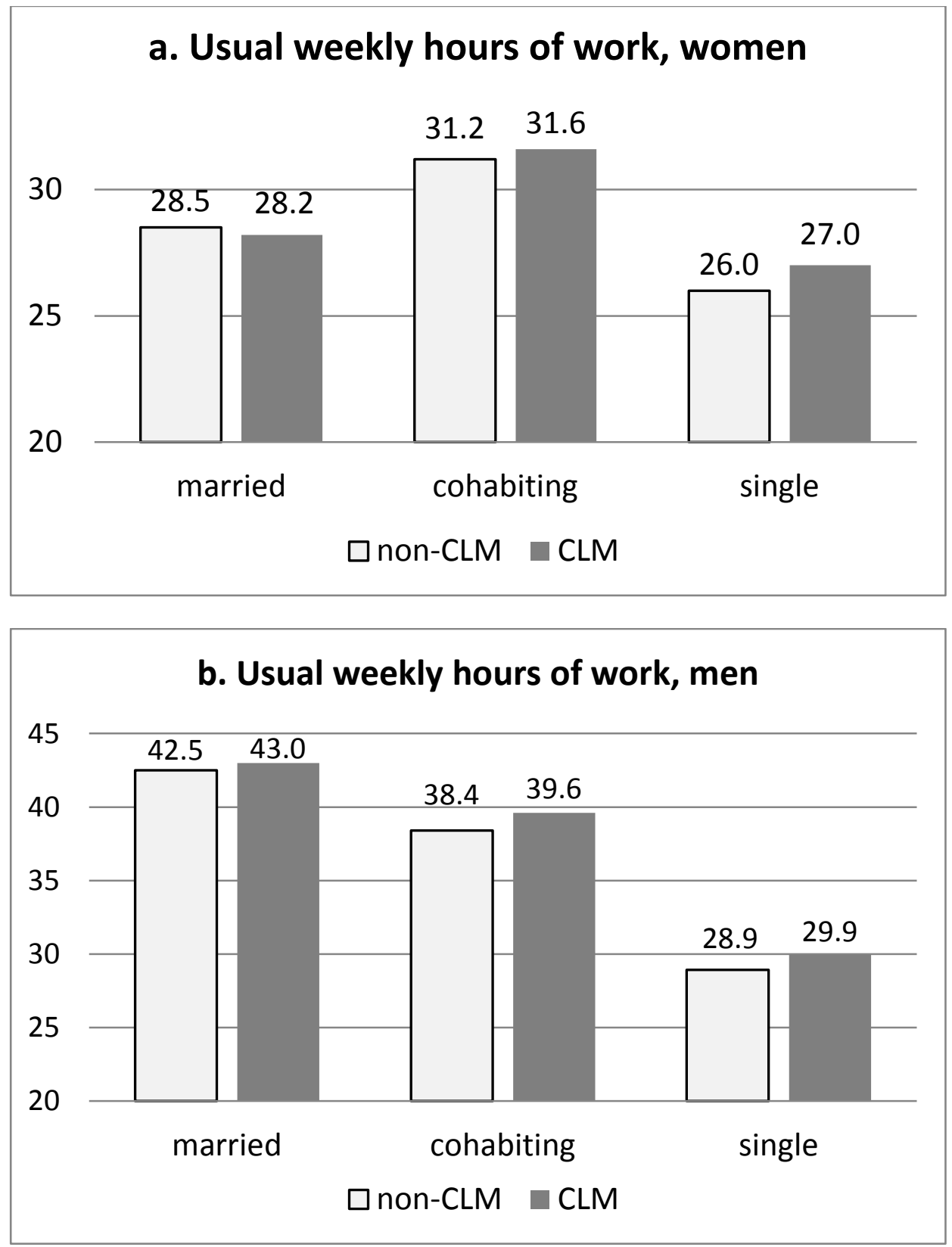
Figure 2. Daily Minutes in Household Production and Paid Work for Women and Men by Presence of CLM and Type of Living Arrangement. US-born individuals ages 18-35, ATUS 2003-2011.
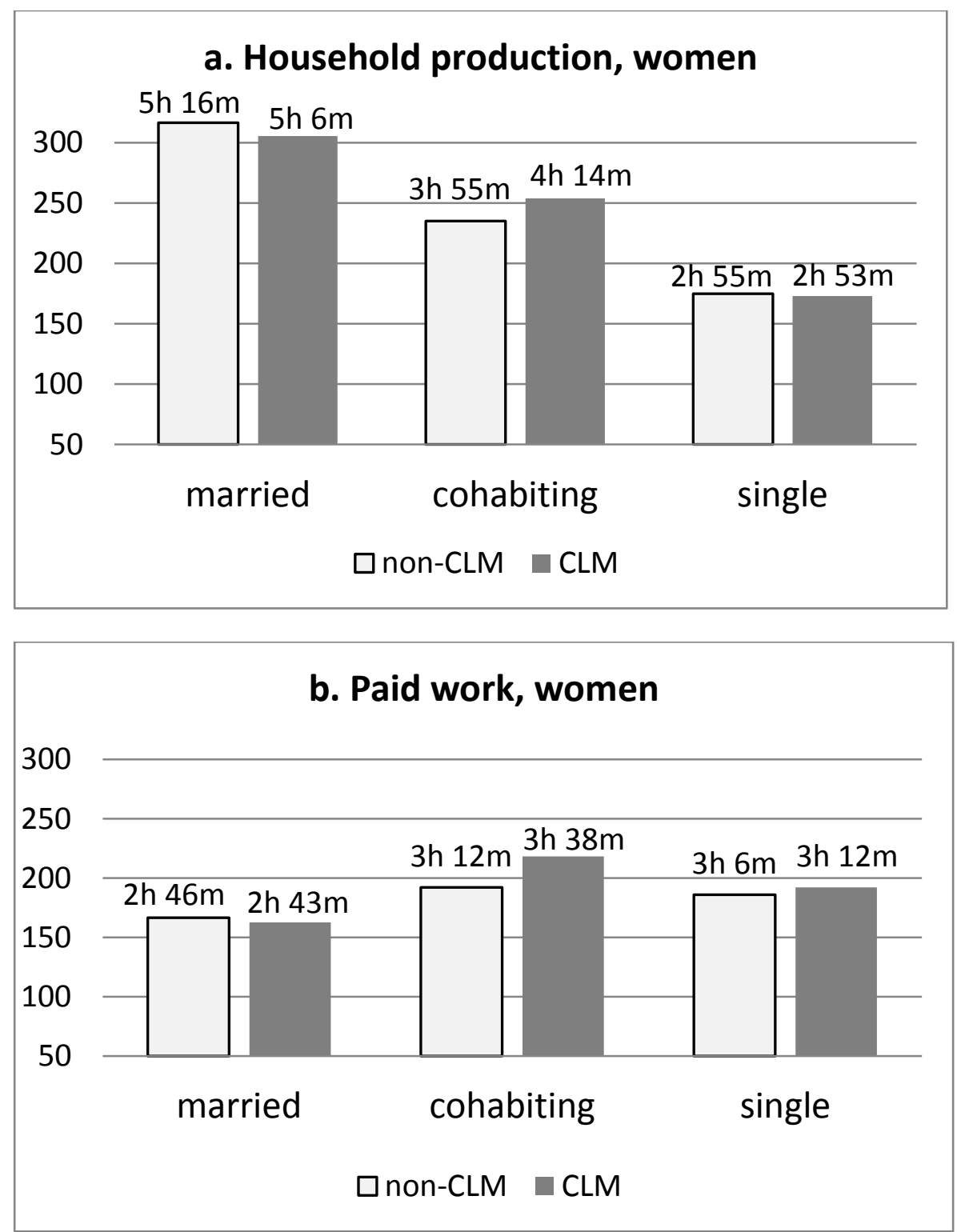

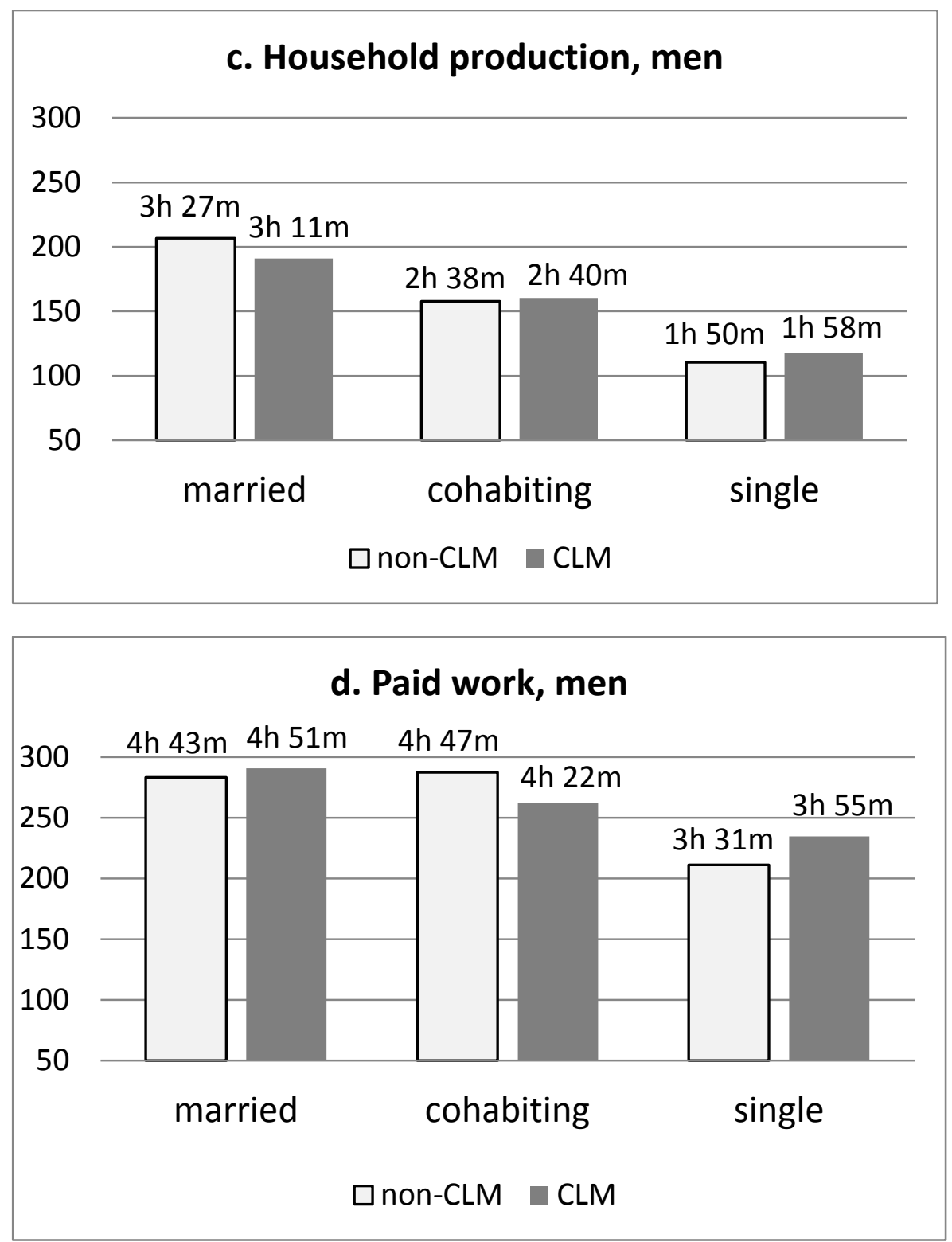
Table 1. Sample means. CPS 1995-2011 and ATUS 2003-11. US born respondents age 18-35.

\begin{tabular}{|c|c|c|c|c|c|c|c|c|}
\hline & \multicolumn{4}{|c|}{ WOMEN } & \multicolumn{4}{|c|}{ MEN } \\
\hline & \multicolumn{2}{|c|}{ CPS, CLM 21.6\% } & \multicolumn{2}{|c|}{ ATUS, CLM 19.8\% } & \multicolumn{2}{|c|}{ CPS, CLM 21.4\% } & \multicolumn{2}{|c|}{ ATUS, CLM $20.1 \%$} \\
\hline & $\begin{array}{l}\text { non- } \\
\text { CLM }\end{array}$ & CLM & $\begin{array}{l}\text { non- } \\
\text { CLM }\end{array}$ & CLM & $\begin{array}{l}\text { non- } \\
\text { CLM }\end{array}$ & CLM & $\begin{array}{l}\text { non- } \\
\text { CLM }\end{array}$ & CLM \\
\hline \multicolumn{9}{|l|}{ Individual characteristics } \\
\hline Married & 0.384 & 0.431 & 0.432 & 0.492 & 0.318 & 0.363 & 0.354 & 0.408 \\
\hline Cohabiting & 0.090 & 0.076 & 0.078 & 0.062 & 0.083 & 0.071 & 0.073 & 0.064 \\
\hline Age & 26.5 & 26.5 & 26.9 & 27.2 & 26.4 & 26.4 & 26.6 & 26.6 \\
\hline No high school diploma & 0.114 & 0.127 & 0.080 & 0.086 & 0.138 & 0.150 & 0.099 & 0.122 \\
\hline Some college & 0.367 & 0.360 & 0.362 & 0.355 & 0.330 & 0.328 & 0.358 & 0.322 \\
\hline College degree & 0.186 & 0.177 & 0.238 & 0.253 & 0.159 & 0.153 & 0.206 & 0.194 \\
\hline Graduate degree & 0.053 & 0.042 & 0.087 & 0.062 & 0.040 & 0.038 & 0.058 & 0.058 \\
\hline Black & 0.159 & 0.150 & 0.109 & 0.097 & 0.137 & 0.130 & 0.081 & 0.071 \\
\hline Hispanic & 0.083 & 0.136 & 0.082 & 0.154 & 0.087 & 0.136 & 0.080 & 0.139 \\
\hline Asian & 0.019 & 0.008 & 0.018 & 0.004 & 0.021 & 0.008 & 0.024 & 0.008 \\
\hline Other race & 0.014 & 0.013 & 0.048 & 0.037 & 0.013 & 0.012 & 0.055 & 0.043 \\
\hline Employed & 0.687 & 0.688 & 0.733 & 0.732 & 0.756 & 0.785 & 0.817 & 0.846 \\
\hline Full time employed & 0.533 & 0.548 & 0.503 & 0.512 & 0.701 & 0.729 & 0.675 & 0.709 \\
\hline Usual hours of work & 27.4 & 27.8 & 26.3 & 26.7 & 34.0 & 35.4 & 34.1 & 36.1 \\
\hline Presence of children $<6$ & 0.285 & 0.311 & 0.365 & 0.406 & 0.179 & 0.209 & 0.236 & 0.273 \\
\hline Children 6-17 & 0.147 & 0.165 & 0.115 & 0.128 & 0.068 & 0.079 & 0.056 & 0.063 \\
\hline Number of children & 0.824 & 0.926 & 0.843 & 1.010 & 0.458 & 0.550 & 0.492 & 0.584 \\
\hline Student & 0.191 & 0.174 & 0.249 & 0.222 & 0.179 & 0.170 & 0.221 & 0.223 \\
\hline Metropolitan residence & 0.269 & 0.268 & 0.68 & 0.63 & 0.261 & 0.263 & 0.694 & 0.607 \\
\hline Unearned income & 53,331 & 49,324 & 44,588 & 40,975 & 49,601 & 43,524 & 43,911 & 39,805 \\
\hline \multicolumn{9}{|l|}{ State characteristics } \\
\hline Community property & 0.249 & 0.360 & 0.241 & 0.377 & 0.256 & 0.353 & 0.251 & 0.345 \\
\hline Sex ratio & 0.997 & 0.994 & 0.986 & 0.985 & 0.998 & 0.995 & 0.987 & 0.987 \\
\hline College educated adults & 25.7 & 24.5 & 27.4 & 26.5 & 25.8 & 24.6 & 27.3 & 26.5 \\
\hline Unemployment rate & 5.9 & 5.4 & 6.7 & 6.0 & 6.0 & 5.4 & 6.8 & 6.0 \\
\hline Median hhold income & 51,957 & 49,083 & 51,911 & 49,492 & 52,046 & 49,216 & 51,849 & 49,665 \\
\hline Welfare & 707 & 611 & 692 & 613 & 710 & 614 & 695 & 618 \\
\hline Urban population share & 79.1 & 75.5 & 79.6 & 76.9 & 79.3 & 75.5 & 79.4 & 76.8 \\
\hline Northeast & & & 0.19 & 0.10 & & & 0.19 & 0.10 \\
\hline Midwest & & & 0.29 & 0.13 & & & 0.29 & 0.13 \\
\hline West & & & 0.23 & 0.19 & & & 0.24 & 0.20 \\
\hline$N$ & 244,583 & 78,275 & 12,063 & 3,281 & 222,489 & 70,556 & 8,576 & 2,452 \\
\hline
\end{tabular}

Notes:

- Shares of college-educated adults are obtained from http://www.census.gov/hhes/socdemo/education/data/census/index.html.

- Population is from the Census website,various pages, for example 2010-11 numbers can be found at http://www.census.gov/popest/data/state/totals/2011/index.html. 
Notes (cont.)

- Median household income is in Table H-8 at http://www.census.gov/hhes/www/income/data/historical/household/.

- Shares of urban population are from Iowa Community Indicators program http://www.icip.iastate.edu/tables/population/urban-pct-states .

- We adjust nominal values to 2010 prices using Consumer Price Index from $\mathrm{ftp}: / / \mathrm{ftp} . \mathrm{bls} . \mathrm{gov} / \mathrm{pub} / \mathrm{special}$.requests/cpi/cpiai.txt .

- Unemployment rates are annual averages by state obtained from BLS (http://www.bls.gov/data/).

- Sex ratios are calculated from Census 1990, 2000 and American Community Surveys 20046 by dividing the number of men in each 5 -year age group by the number of women who are 2 years younger. For example, in order to get a sex ratio for women aged 30-35, we divide the number of men aged 32-37 by the number of women aged 30-35.

- "Welfare" is the maximum TANF+SNAP benefits for a family of two, in 2010 dollars obtained from the University of Kentucky Center for Poverty Research http://www.ukcpr.org/AvailableData.aspx 
Table 2. Employment and labor supply regression coefficients, CPS 1995-2011. Full set of controls.

\begin{tabular}{|c|c|c|c|c|c|c|}
\hline \multirow[b]{2}{*}{$\begin{array}{l}\text { Model 1:Full set of } \\
\text { controls }\end{array}$} & \multicolumn{3}{|c|}{ WOMEN, N=322,858 } & \multicolumn{3}{|c|}{ MEN, N=293,045 } \\
\hline & $\begin{array}{c}\text { probit } \\
\text { employed }\end{array}$ & $\begin{array}{c}\text { probit } \\
\text { full-time }\end{array}$ & $\begin{array}{c}\text { OLS } \\
\text { hours/week }\end{array}$ & $\begin{array}{c}\text { probit } \\
\text { employed }\end{array}$ & $\begin{array}{c}\text { probit } \\
\text { full-time }\end{array}$ & $\begin{array}{c}\text { OLS } \\
\text { hours/week }\end{array}$ \\
\hline Individual characteristics & 1 & 2 & 3 & 4 & 5 & 6 \\
\hline CLM*Single & -0.01 & $-0.02 *$ & $\begin{array}{l}-0.54 \\
\end{array}$ & $-0.02 * *$ & $\mathbf{0}$ & -0.1 \\
\hline CLM*Married & $-0.02 *$ & $-0.03 * * *$ & $-1.07 * * *$ & 0 & 0.01 & -0.15 \\
\hline CLM*Cohabiting & -0.02 & $-0.03 *$ & $-0.84 * *$ & -0.01 & 0.02 & 0.34 \\
\hline Married & 0 & $0.03 * * *$ & $0.70 * * *$ & $0.13^{* * *}$ & $0.16^{* * *}$ & $5.72 * * *$ \\
\hline Cohabiting & $0.03^{* * *}$ & $0.10 * * *$ & $3.11 * * *$ & $0.07 * * *$ & $0.12 * * *$ & $5.23 * * *$ \\
\hline Age & $0.04 * * *$ & $0.13^{* * *}$ & $3.14 * * *$ & $0.02 * * *$ & $0.09 * * *$ & $2.84 * * *$ \\
\hline Age-squared & $-0.07 * * *$ & $-0.23 * * *$ & $-5.35 * * *$ & $-0.03 * * *$ & $-0.15 * * *$ & $-4.69 * * *$ \\
\hline No high school & $-0.16^{* * *}$ & $-0.17 * * *$ & $-6.32 * * *$ & $-0.13 * * *$ & $-0.16 * * *$ & $-5.89 * * *$ \\
\hline Some college & $0.07 * * *$ & $0.04 * * *$ & $2.24 * * *$ & $0.05^{* * *}$ & $0.01 * * *$ & $1.23 * * *$ \\
\hline College degree & $0.15^{* * * *}$ & $0.13 * * *$ & $4.99 * * *$ & $0.11 * * *$ & $0.06^{* * *}$ & $2.84 * * *$ \\
\hline Graduate degree & $0.19 * * *$ & $0.19 * * *$ & $8.03 * * *$ & $0.12 * * *$ & $0.04 * * *$ & $4.43 * * *$ \\
\hline Black & $-0.05 * * *$ & $0.03 * * *$ & $-0.43 * * *$ & $-0.14 * * *$ & $-0.12 * * *$ & $-5.43 * * *$ \\
\hline Hispanic & 0 & $0.03 * * *$ & -0.13 & $-0.02 * * *$ & $-0.02 * * *$ & $-1.78 * * *$ \\
\hline Asian & $-0.08 * * *$ & $-0.02 * *$ & $-1.87 * * *$ & $-0.08 * * *$ & $-0.05 * * *$ & $-3.10 * * *$ \\
\hline Other race & $-0.10 * * *$ & 0 & $-1.14 * * *$ & $-0.12 * * *$ & $-0.09 * * *$ & $-3.78 * * *$ \\
\hline Metropolitan status & $-0.02 * * *$ & 0 & $-0.36 * * *$ & $-0.01 * * *$ & $-0.02 * * *$ & $-0.91 * * *$ \\
\hline Student & $-0.18 * * *$ & $-0.32 * * *$ & $-8.96 * * *$ & $-0.22 * * *$ & $-0.33 * * *$ & $-10.59 * * *$ \\
\hline Unearned income & $-0.00 * * *$ & $-0.01 * * *$ & $-0.39 * * *$ & $-0.01 * * *$ & $-0.01 * * *$ & $-0.32 * * *$ \\
\hline Presence of kids <6 & $-0.09 * * *$ & $-0.08 * * *$ & $-2.30 * * *$ & $0.05^{* * *}$ & $0.09 * * *$ & $1.76^{* * *}$ \\
\hline Presence of kids < 18 & $0.03 * * *$ & $0.04 * * *$ & $2.05^{* * *}$ & $0.04 * * *$ & $0.07 * * *$ & $1.58 * * *$ \\
\hline Number of children & $-0.05 * * *$ & $-0.07 * * *$ & $-2.63 * * *$ & $-0.01 * * *$ & $-0.02 * * *$ & $-0.17 * * *$ \\
\hline \multicolumn{7}{|l|}{ State characteristics } \\
\hline Community property & $0.09 * *$ & $0.20^{* * * *}$ & 0.72 & $0.16^{* * *}$ & $0.08^{*}$ & 0.76 \\
\hline Sex ratio & $-0.07 * *$ & $-0.19 * * *$ & $-8.07 * * *$ & $-0.06 * *$ & $-0.08 * * *$ & $-6.96 * * *$ \\
\hline College educated adults & 0 & $0.01 * * *$ & $0.26 * * *$ & 0 & 0 & -0.05 \\
\hline Unemployment rate & $-0.01 * * *$ & $-0.01 * * *$ & $-0.26 * * *$ & $-0.01 * * *$ & $-0.01 * * *$ & $-0.40 * * *$ \\
\hline Log median state income & 0.04 & $0.06^{* *}$ & $1.52 *$ & 0.04 & $0.09 * * *$ & $2.34 * *$ \\
\hline Welfare & 0 & $-0.03 *$ & -0.47 & -0.01 & 0 & 0.2 \\
\hline Urban population share & 0 & $-0.00 * * *$ & $-0.12 * * *$ & $-0.00 * * *$ & 0 & 0.04 \\
\hline State dummies & yes & yes & yes & yes & yes & yes \\
\hline Time dummies & yes & yes & yes & yes & yes & yes \\
\hline R-squared & & & 0.19 & & & 0.30 \\
\hline
\end{tabular}

Note: The table shows marginal effects from probit regressions and OLS coefficients. Here and in the rest of the paper significance is marked as follows: * significant at $10 \%$; ** significant at 5\%; *** significant at $1 \%$ 
Table 3. Coefficients on the variables of interest, respondents without college degree, by age and race, CPS 1995-2011.

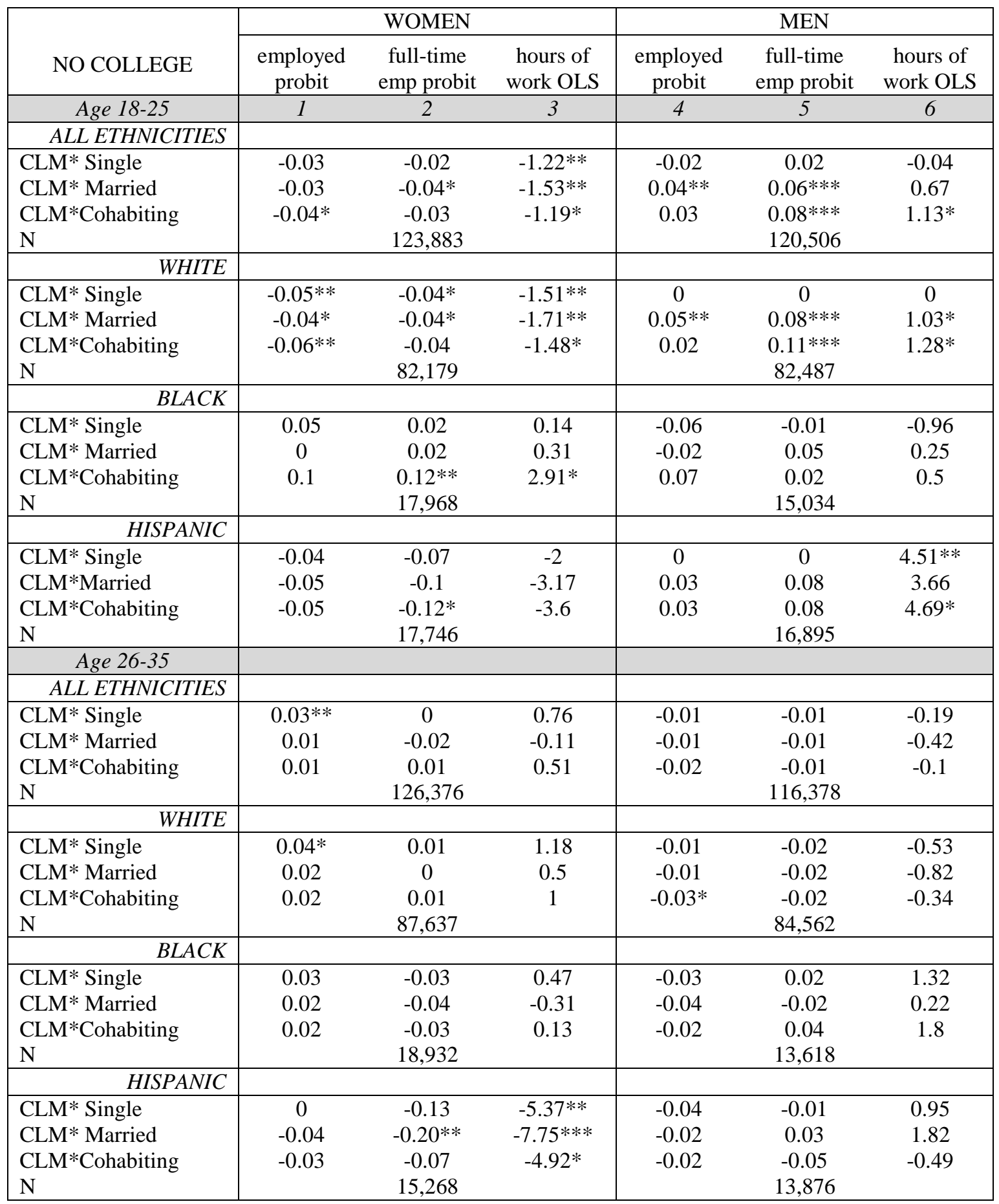


Table 4. Coefficients on the variables of interest, college-educated respondents, by age and race, CPS 1995-2011.

\begin{tabular}{|c|c|c|c|c|c|c|}
\hline \multirow[b]{2}{*}{ COLLEGE } & \multicolumn{3}{|c|}{ WOMEN } & \multicolumn{3}{|c|}{ MEN } \\
\hline & $\begin{array}{c}\text { employed } \\
\text { probit }\end{array}$ & $\begin{array}{c}\text { full-time } \\
\text { emp probit }\end{array}$ & $\begin{array}{c}\text { hours of } \\
\text { work OLS }\end{array}$ & $\begin{array}{c}\text { employed } \\
\text { probit }\end{array}$ & $\begin{array}{c}\text { full-time } \\
\text { emp probit }\end{array}$ & $\begin{array}{c}\text { hours of } \\
\text { work OLS }\end{array}$ \\
\hline & 1 & 2 & 3 & 4 & 5 & 6 \\
\hline \multicolumn{7}{|c|}{ ALL ETHNICITIES } \\
\hline CLM & -0.01 & 0 & -0.37 & 0.01 & 0 & 0.6 \\
\hline CLM* Married & $-0.03 * * *$ & $-0.04 *$ & $-1.38 * *$ & 0 & 0 & 0.48 \\
\hline CLM $*$ Cohabiting & -0.02 & $-0.06 * *$ & $-1.91 * * *$ & -0.01 & 0 & 0.31 \\
\hline $\mathrm{N}$ & & 72,599 & & & 56,161 & \\
\hline \multicolumn{7}{|c|}{ WHITE } \\
\hline CLM* Single & $-0.03 * *$ & 0 & -0.4 & 0.01 & 0 & $0.98 *$ \\
\hline CLM* Married & $-0.05 * * *$ & $-0.04 *$ & $-1.54 * *$ & 0 & 0 & 0.71 \\
\hline CLM*Cohabiting & $-0.04 *$ & $-0.06^{*}$ & $-2.13 * * *$ & -0.01 & 0 & 0.38 \\
\hline $\mathrm{N}$ & & 58,804 & & & 46,894 & \\
\hline \multicolumn{7}{|c|}{$B L A C K$} \\
\hline CLM* Single & 0.05 & -0.06 & -1.87 & -0.03 & 0.01 & -1.68 \\
\hline CLM* Married & 0.03 & -0.04 & -0.88 & -0.09 & -0.09 & -3.02 \\
\hline CLM*Cohabiting & 0.05 & -0.08 & -1.57 & -0.04 & 0.02 & 0.94 \\
\hline $\mathrm{N}$ & & 6,114 & & & 3,439 & \\
\hline \multicolumn{7}{|c|}{ HISPANIC } \\
\hline CLM* Single & 0.07 & 0.12 & 3.72 & -0.03 & $-0.34 * * *$ & $-6.97 * *$ \\
\hline CLM* Married & 0.05 & 0.08 & 3.09 & -0.02 & $-0.32 * * *$ & $-5.79 *$ \\
\hline CLM*Cohabiting & 0.08 & 0.01 & 2.59 & -0.04 & $-0.33 * *$ & $-9.13 * *$ \\
\hline $\mathrm{N}$ & & 4,642 & & & 3,284 & \\
\hline
\end{tabular}


Table 5 Summary of CPS results for labor supply outcomes.

PANEL A. SUMMARY OF RESULTS FOR ALL RESPONDENTS AND THOSE WITH COLLEGE (based on Tables 2 and 4)

\begin{tabular}{|l|c|c|c|c|}
\hline & \multicolumn{2}{|c|}{ women } & \multicolumn{2}{c|}{ men } \\
\cline { 1 - 4 }$\underline{18-35}$ & All & College & allege $*$ \\
\cline { 1 - 3 } single & Neg FT & & Neg LF & \\
\hline married & Neg LF FT hs & Neg LF FT hs & & \\
\hline cohab & Neg FT hs & Neg FT hs & & \\
\hline
\end{tabular}

Notes: Neg and Pos stand for 'negative' and 'positive' signs of CLM (common-law marriage) availability; LF: labor force participation; FT: full-time employment; hs: hours of work.

*When college educated men are broken down by ethnicity, we find a Positive effect on hours for white single men and a Negative effect on FT and hours for Hispanic men (in all relationship status).

PANEL B. SUMMARY OF RESULTS FOR RESPONDENTS WITH NO COLLEGE (based on Table 3)

\begin{tabular}{|c|c|c|c|c|c|c|c|c|}
\hline & \multicolumn{4}{|c|}{ Women no college } & \multicolumn{4}{|c|}{ Men no college } \\
\hline & All ethn. & white & black & Hisp. & All ethn. & white & black & Hisp. \\
\hline $18-25$ & & & & & & & & \\
\hline$\overline{\text { single }}$ & Neg hs & Neg LF FT hs & & & & & & Pos hs \\
\hline married & Neg FT hs & Neg LF FT hs & & & Pos LF FT & Pos LF FT hs & & \\
\hline cohab & Neg LF hs & Neg LF hs & Pos FT hs & Neg FT & Pos FT hs & Pos FT hs & & Pos hs \\
\hline $26-35$ & & & & & & & & \\
\hline single & Pos LF & Pos LF & & Neg hs & & & & \\
\hline married & & & & Neg FT hs & & & & \\
\hline cohab & & & & Neg hs & & & & \\
\hline
\end{tabular}


Table 6. Household production and total work regressions with full set of controls, tobit marginal effects. US born women \& men age 18-35, ATUS 2003-2011.

\begin{tabular}{|c|c|c|c|c|}
\hline & \multicolumn{2}{|c|}{ WOMEN, $\mathrm{N}=15,344$} & \multicolumn{2}{|c|}{ MEN, $\mathrm{N}=11,028$} \\
\hline & h.prod. & total work & h.prod. & total work \\
\hline \multicolumn{5}{|l|}{ Individual characteristics } \\
\hline CLM* Single & $-11.34 * *$ & -2.5 & 6.9 & $22.13 * * *$ \\
\hline CLM *Married & $-14.59 * *$ & $-14.29 * *$ & $-13.92 *$ & -14.69 \\
\hline CLM $*$ Cohabiting & 13.27 & $39.20 * *$ & 10.49 & -8.07 \\
\hline Married & $38.08 * * *$ & $11.05 * *$ & $27.97 * * *$ & $50.82 * * *$ \\
\hline Cohabiting & $32.76 * * *$ & $15.76^{* *}$ & $26.72 * * *$ & $60.45 * * *$ \\
\hline Age & $-10.38 * * *$ & $30.89 * * *$ & $-7.13^{*}$ & $32.02 * * *$ \\
\hline Age-sq & $22.10 * * *$ & $-51.25 * * *$ & $17.43^{* *}$ & $-49.81 * * *$ \\
\hline No high school diploma & 0.77 & $-45.31 * * *$ & 0.22 & $-34.23 * * *$ \\
\hline Some college & $9.16^{* *}$ & $20.54 * * *$ & 5.84 & $21.85^{* * *} *$ \\
\hline College degree & 4.5 & $32.94 * * *$ & 8.97 & $29.37 * * *$ \\
\hline Graduate degree & $14.58 * *$ & $45.45 * * *$ & 8.24 & $48.76 * * *$ \\
\hline Black & $-52.32 * * *$ & $-49.46^{* * *}$ & $-33.75 * * *$ & $-60.07 * * *$ \\
\hline Hispanic & $-9.20 *$ & -1.13 & -4.49 & 6.71 \\
\hline Asian & -13.78 & -12.86 & $-34.07 * *$ & -17.37 \\
\hline Other race & 8.98 & -4.15 & $20.96^{* *}$ & -19.08 \\
\hline Metropolitan residence & 6.2 & -1.83 & -8.1 & 5.93 \\
\hline Presence of kids $<6$ & $163.19 * * *$ & $99.99 * * *$ & $86.16 * * *$ & $82.48 * * *$ \\
\hline Presence of kids $<18$ & $73.96 * * *$ & $64.87 * * *$ & $40.38 * * *$ & $46.67 * * *$ \\
\hline Number of children & $19.88 * * *$ & $10.16^{* * *}$ & 2.95 & 0.99 \\
\hline Student & $-18.76^{* * * *}$ & $-77.52 * * *$ & $-22.16^{* * *}$ & $-113.57 * * *$ \\
\hline Summer & -3.83 & -4.95 & 6.82 & $10.41^{*}$ \\
\hline Friday & -2.41 & $-13.72 * *$ & 7.79 & 6.25 \\
\hline Saturday & $37.31 * * *$ & $-149.22 * * *$ & $69.97 * * *$ & $-179.01 * * *$ \\
\hline Sunday & $15.05^{* * *}$ & $-192.70 * * *$ & $61.13 * * *$ & $-225.98 * * *$ \\
\hline Holiday & $-22.52 *$ & $-236.00 * * *$ & 19.17 & $-291.36 * * *$ \\
\hline \multicolumn{5}{|c|}{ State characteristics \& time dummies } \\
\hline Community property & -5.68 & -8.51 & 5.88 & -7.73 \\
\hline Sex ratio & $118.33^{* * *}$ & 36.76 & -18.97 & 49.55 \\
\hline College educated adults & 0.33 & -0.32 & -0.4 & $-3.62 * * *$ \\
\hline Unemployment rate & -0.63 & 0.6 & 2.72 & $-6.16 * * *$ \\
\hline Log median state income & $-73.42 * * *$ & 7 & $74.20 * *$ & $70.08^{*}$ \\
\hline Welfare & 7.18 & -15.92 & -10.56 & 19.66 \\
\hline Urban population share & 0.21 & -0.11 & $-0.45^{*}$ & 0.06 \\
\hline Northeast & $12.24 * *$ & $14.90^{* *}$ & 3.77 & -12.09 \\
\hline Midwest & -6.02 & $10.00 *$ & $14.43 * *$ & -6.45 \\
\hline West & 4.82 & 8.46 & 1.31 & -5.17 \\
\hline Year dummies & yes & yes & yes & yes \\
\hline
\end{tabular}

Notes: Dependent variables are daily minutes spent in household production and total work. The latter is defined as household production plus paid work. Survey weights are applied to account evenly for all days of the week. 
Table 7. Coefficients on the variables of interest, regressions by age, education and race, ATUS 2003-2011.

\begin{tabular}{|c|c|c|c|c|}
\hline & \multicolumn{2}{|c|}{ WOMEN } & \multicolumn{2}{|c|}{ MEN } \\
\hline & h.prod. & total work & h.prod. & total work \\
\hline \multicolumn{5}{|c|}{ Age $18-25$} \\
\hline CLM*Single & $-17.88 * *$ & 0.57 & -4.24 & $24.57 *$ \\
\hline CLM*Married & -7.89 & -15.05 & -25.37 & -11.61 \\
\hline CLM*Cohabiting & 17.74 & 39.18 & 30.52 & 67.32 \\
\hline $\mathrm{N}$ & & 4,779 & & 3,641 \\
\hline \multicolumn{5}{|c|}{ Age 26-35 } \\
\hline CLM*Single & -4.8 & -0.75 & $18.97 *$ & 19.29 \\
\hline CLM*Married & $-14.91 * *$ & $-16.81 * *$ & -10.29 & -14.47 \\
\hline CLM $*$ Cohabiting & 10.71 & 26.38 & -1.62 & $-67.94 * *$ \\
\hline $\mathrm{N}$ & & 10,565 & & 7,387 \\
\hline \multicolumn{5}{|c|}{ No college degree } \\
\hline CLM*Single & $-14.57 * *$ & -7.64 & 3.06 & $21.37 * *$ \\
\hline CLM*Married & $-14.31 *$ & $-16.25 *$ & -13.01 & -14.27 \\
\hline CLM*Cohabiting & 17.58 & 27.05 & 5.43 & -17.32 \\
\hline $\mathrm{N}$ & & 10,613 & & 7,897 \\
\hline \multicolumn{5}{|c|}{ College degree } \\
\hline CLM*Single & -6.21 & 16.46 & 21.62 & $29.76^{*}$ \\
\hline CLM*Married & -14.38 & -12.88 & -11.06 & -15.92 \\
\hline CLM*Cohabiting & -4.11 & $80.55 * * *$ & 22.79 & 40.15 \\
\hline $\mathrm{N}$ & & 4,731 & & 3,131 \\
\hline \multicolumn{5}{|c|}{ Non-black } \\
\hline CLM*Single & $-13.58 * *$ & -5.55 & $11.40 *$ & $30.14 * * *$ \\
\hline CLM*Married & $-16.94 * * *$ & $-13.85 * *$ & $-13.19 *$ & -13.31 \\
\hline CLM*Cohabiting & 14.29 & $42.24 * *$ & 11.77 & -0.53 \\
\hline $\mathrm{N}$ & & 13,007 & & 9,809 \\
\hline \multicolumn{5}{|c|}{ Black } \\
\hline CLM*Single & 0.4 & 3.61 & $-39.26 * *$ & $-63.11 * *$ \\
\hline CLM*Married & 17.55 & -21.2 & -31.36 & -18.74 \\
\hline CLM $*$ Cohabiting & -17.27 & -34.9 & -34.27 & -109.97 \\
\hline $\mathrm{N}$ & & 2,337 & & 1,219 \\
\hline
\end{tabular}

